\title{
Determinants of Women Entrepreneurs' Performance in Ethiopia (Evidence from Hawassa City Administration)
}

\author{
Fitsum Awoke (MBA) Sintayehu Assefa (PhD Candidate) \\ Department of Management, University of Hawassa - Ethiopia
}

\begin{abstract}
This study is conducted to assess the determinants of women entrepreneurs' performance: the case of Hawassa City Administration, Ethiopia. The study employed an explanatory research design with quantitative and qualitative research approaches. The required data were collected from 278 selected women entrepreneurs by adopting a multistage sampling technique. The data collected through questionnaire were analyzed using SPSS software version 21. Inferential statistics such as correlation and multiple linear regression were applied. The data collected through key informant interview was analyzed qualitatively using narration for triangulation. The findings of the study showed that educated women had better entrepreneurship performance since they can easily use technologies and can get management experience easily. In the same way, women entrepreneurs experience to increase their profitability. Likewise, having sufficient start up capital for business, access to credit to expand an existing business, having sufficient working capital, and having had collateral to get credit are significant factors that affect women entrepreneurs' performance. Equally, having high production capacity due to available capital, delivering a product that meets customers need with a fair price, having convenient display room and selling premises, and having good market linkages are significant factors that affect women entrepreneurs' performance. Furthermore, having the desire for achievement, independence, wealth and having self-discovery and job satisfaction are significant determinants of women entrepreneurs' performance. Therefore, the researcher recommends Hawassa city administration in collaboration with other NGO who were working with women should give continuous training to enable them to be more productive. Likewise, the financial institutions in the city should arrange long-term financial credit for women entrepreneurs.
\end{abstract}

Keywords: Women Enterprenuers, Performance, Hawassa City

DOI: $10.7176 / \mathrm{EJBM} / 11-22-02$

Publication date: August $31^{\text {st }} 2019$

\section{INTRODUCTION}

Entrepreneurship could be a dynamic phenomenon that localizes economies, enables entrepreneurs, establish business, and creates opportunities that attract other businesses either as suppliers or clients or even competitors (Nkurunziza, 2012). According to International Development Research Centre (IDRC, 2013), women's position in the household is impacted by a myriad of factors. These may include; rights to property, social and cultural norms related to childcare and paid and unpaid care work, social and cultural norms related to work, value placed on girls' education, intra-household dynamics and bargaining power, and burdens of unpaid productive or care work.

Women's work may be constrained by discriminatory legal and regulatory barriers, limited access to financial and physical assets and market information, fewer social networks and business connections, limited access to education and skills development, and weaker bargaining power in labor markets (Amer, 2013). In such conditions, light manufacturing are an attractive choice in the effort to capitalize on human and natural resource endowments and generate more jobs for the many low-skilled laborers in the informal sector. It is labor intensive and thereby allows low-income countries to compete by leveraging the low cost of their labor. It has been a crucial steppingstone in most successful developing economies, including the Asian tigers, Mauritius and, more recently, China and Vietnam (Dinh, 2011).

In Ethiopia, Micro and Small Enterprise (MSE) is prioritized as an important means of economic diversification, job creation, income generation and equity distribution as indispensable poverty reduction sector since 2006. The MSEs are the light manufacturing sector that occupies a place of strategic importance in any economic structure. They play a key role in the industrialization and development of a country. This is because, they are part of entrepreneur activities that provide an immediate large scale employment, and they need lower investment, offer a method of ensuring a more equitable distribution of national income and facilitate an effective mobilization of resources and skill (Geneti, 2018).

This confirms us that the most important determinant of any country's competitiveness is utilization of its workforce productivity. One of these work forces is women and they account for one-half of the potential talent base throughout the world in general and in Ethiopia in particular. Thus closing gender gaps is not only a matter of human rights and equity; rather it is an indication of efficiency (Hausmann \& Zahidi, 2012).

Women in Ethiopia in general and in the study area in particular like many other developing countries have low access to economic resources and other human rights. This implies, women's participation in economic 
activities such as MSEs in general and self-employment in particular is limited (Rahel and Paul, 2010).

So, it is vital to address the economically disadvantaged women through women operated micro and small scale enterprises to solve their economic problem and sustain development. Therefore, the study aims to identify the determinants of women entrepreneurs' performance in Hawassa city administration and showed some of the issues that need to be addressed in the research.

\subsection{Statement of the Problem}

For mitigating the socioeconomic problems of the country, women are very important. However, women in urban areas are marginalized due to their low status and unemployment as well as lack of livelihood options (Mabala, 2011). Economic dependency, poverty and unemployment are the most crucial problems faced by the women in Ethiopia. Likewise, the differentials of the unemployment rate by sex show that female unemployment rate $(24.7 \%)$ is more than double as compared to male (9.4\%) counterparts (CSA, 2016). Among the total population in the study area (343175) male constitute 176,599 and 166,576 are females, which indicate that females constitute half of the population (HCAFEDD, 2016). Both male and female take part in the entrepreneurship activity, however the percentage share of women entrepreneurs in the city were much less than their counter parts (Bereket, 2017).

According to Hawassa city trade and industry office (2018), the total entrepreneur enrolled in micro and small scale business was $30.8 \%$. This implies that even though women in the city constitute half of the population, the percentage share of entrepreneurs is very small. The city trade and industry office further indicated in its annual report that greater number of women entrepreneurs registered but they failed to continue more than a quarter. Numerically, about $60 \%$ of the firms collapsed due to many reasons. Among many reasons, the number one challenge was indicated as unprofitable (Global Entrepreneurship Monitors, 2010). This indicates that there are challenges that hold back them not to participate actively in entrepreneurship which contributes to unprofitably.

It is also noted that scientific studies about women entrepreneurship had received less attention than research on entrepreneurship in general (Ngare, 2013; Mulugeta, 2010). Therefore, the statement of the problem of this study is to identify the determinants of women entrepreneurs' performance in Hawassa city administration.

\subsection{Objectives of the Study}

The general objective of the study is to identify the determinants of women entrepreneurs' performance in Hawassa city administration, Southern Nations Nationalities and Representative State, Ethiopia.

The specific objectives of the study are

1. To examine the relationship between economic factors and women entrepreneurs performance in the study area.

2. To find out the relationship between marketing factors and women entrepreneurs performance in the study area.

3. To identify the relationship between institutional factors and women entrepreneurs performance in the study area.

4. To investigate relationship between socio-demographic factors and women entrepreneurs performance in the study area.

5. To identify the relationship between motivational factors and women entrepreneurs performance in the study area.

6. To identify the relationship between cultural factors and women entrepreneurs performance in the study area.

\section{Review of Related Literature}

This part of the study aim to show literature important to the study and to provide a theoretical frame work. This chapter also consists of concepts and definitions, theoretical literature, empirical evidence and conceptual frame work of the study.

\subsection{Concepts and Definitions of Women Entrepreneurship}

The term entrepreneur originated from the French word "entreprendre" signifying "to undertake" in old French; and was first used in 1852 (Porfeli, 2009). The definitions of entrepreneurship and entrepreneur in literature are very diverse and vary as they include human attempts to commerce a new product or service (Jennings, 1994). In similar vein, Jalbert (2000) agrees with the above statement and explains; entrepreneurship exists from a person's "creative spirit into long-term business owner, job creation and economic security" (Jalbert, 2000). Additionally, Cull (2009) describes entrepreneurs as innovators. That is, a person who introduces a unique idea or something new within the economy. Such innovations may be the creation of new products, a process of production and the organization of the industry (Dzisi, 2008).

Entrepreneurship has different meaning by different scholars and disciplines, but they share some common ideas. According to Onuoha (2007), entrepreneurship is the practice of starting new organizations or reviving mature organizations or identifying new businesses opportunities. Entrepreneurship is the process of creating and 
producing value added products by devoting the necessary time and efforts along with financial, psychological and social risk in order to get financial profits, personal satisfaction and independence (Parker, 2009; Cromie and Hayes, 1988; Begley, 1995; Adnan, 2004). In sum, from the above definitions one may define entrepreneurship is a way of creating a new organization or renewing the existing firm has a risk and finally has expected profit or reward.

There are also attempts to suggest definitions of 'female entrepreneur'. Lavoie (1985) for example; defined female entrepreneur as the female head of a business who takes the initiative of launching a new venture; accepts the associated risks, financial, administrative and social responsibilities, and who is effectively in charge of the daily management of the business. Buttner and Moore (1997) identified women entrepreneurs in their study as those having initiated the business, being the owner of at least fifty percent of the business and playing a major managerial role in the business. Chu (2000) defined women entrepreneurs as female owner-managers who may acquire business ownership through their own creation, inheritance, or jointly established with or without family members, being directors in the establishment and must be actively involved in the business.

Women entrepreneurs are simply women that participate in total entrepreneurial activities, who take the risks involved in combining resources together in a unique way so as to take advantage of the opportunity identified in their immediate environment through production of goods and services. Most of them are involved in Micro, Small and Medium Scale Enterprises (MSMEs) which contribute more than $97 \%$ of all enterprises, $60 \%$ of the nation's GDP and $94 \%$ of the total share of the employment (Ndubusi, 2004).

\subsubsection{The need of women entrepreneurship}

All the stakeholders of women entrepreneurs should engage in deliberate efforts to develop financial and support programs that meet the needs of women entrepreneurs in a country. Existing financial and business development institutions and donors should be encouraged to develop specialized programs and schemes to address the needs of these women. There is also a need to train women who manage these business enterprises in the country with financial management to enable them manage their enterprises; handle the loans given in a better and efficient manner. They also need to undergo training on record keeping. Therefore, lack of general business knowledge or management skill can hinder start-up and growth of business organizations. Thus, for women with the intention of venturing into business with no prior business training, it is important for them to get into business training if they are to succeed (Ngare, 2013).

According to Orwa (2012), when women want to start and expand an enterprise, it necessarily involves broaching multifaceted subjects such as the empowerment of women. In order for a woman to be empowered, she needs access to and control over the material, human and social resources necessary to make strategic choices, access to market, access to generate income, access to infrastructure services and the like.

Women depend on MSMEs as a source of livelihood essentially because national governments fail to meet their requirements for survival and entrepreneurial aspiration. They have actively engaged and earn their livelihood in small enterprisers where government policies, regulations, owner's business skills, availability of finance, appropriate business trainings, and market matter most for their survival. Even though women entrepreneurs in Ethiopia start a number of new businesses, they find it harder to grow their business to the next higher level. Survival of a business firm is defined as the ability of the firm to continue its operation and remain in business during a certain period of time in a competitive market (Desta, 2008).

Women entrepreneurs play an important role in growth and poverty reduction, not just in Ethiopia. For this reason, while encouraging entrepreneurship in general, it is important to focus in particular on supporting women entrepreneurs in developing countries, for example by getting women to start on micro-entrepreneurships, and then helping them to grow into SMEs with employees, and getting larger companies to grow more quickly. In favor of this, several aid actors, including the World Bank, have announced that they will be expanding their initiatives to support women entrepreneurs in various countries, including Ethiopia (Dott, 2012). This implies that, it is better for developing countries such as Ethiopia to exploit the human skill, material and financial resources of the aiding agents to support women entrepreneurs.

\subsubsection{Determinants of women entrepreneurs' performance}

\subsubsection{Economic Factors}

High capital requirements are a particular problem for women because they typically inherit less than men. They may also inherit less land or real estate, which are important as collateral (World Bank, 2008). High working capital permits to run a huge business; allow using advanced technology which increases the productivity level and quality. Good infrastructure has the effect of promoting MSEs by lowering the cost of doing business (ILO, 2008, Jackie, 2008). Infrastructures' facilitate investment; by reducing time of production and transportation, increase access and dissemination of information. This contributes to increase the profit of the organization.

On the same way a report carried out by Hattab (2008) on Egypt entrepreneurship verified that, to access startup capital can be a major deterrent to startup actions. Banks with respect to this traditionally have not been that eager to finance new businesses, unless they can properly assess the risk. This is most problematic in developing countries. In this regard, Ethiopia as one of the developing countries in the world can also share this 
circumstance.

The binding constraints on entrepreneurship and light manufacturing in Africa have identified. They are said to be the six binding constraints on African competitiveness in light manufacturing and include the availability, cost, and quality of inputs; access to industrial land; access to finance; trade logistics; entrepreneurial capabilities, both technical and managerial; and worker skills. These constraints vary by country, sector, and firm size. From these constraints those that are common constraints among the small firms such as MSEs are entrepreneurial skills and premises, inputs, and finance at startup and running business are the most important constraints (Dinh, 2011).

\subsubsection{Market Factors}

According to Bendixen and Migliorini (2006), the key antecedents that were found to affect the commencement and performance of women owned businesses generally are individual characteristics, organization factors, network factors and environmental factors. The increase of demand initiates the suppliers to produce more. High competition in the market affects newly developed and less capital firms. A suitable area of the enterprise has more contribution for sales and determines the size of customers(Ummah, 2012).

\subsubsection{Institutional Factors}

Prolonged organizational services consume working time of women entrepreneurs. Access adequate and affordable credit a major obstacle for many women-owned SMEs this in turn affect the resources and business of women entrepreneurs. The existence of credit service provides an opportunity of entrepreneurs to start and expand their enterprises. Publicizing clear information by service providers about the service they provide. Information strengthens the decision making ability of entrepreneurs. The imposed tax sometimes not proportional to the profit of the business this discourages women entrepreneurs either to start or continue their business(Stevenson, 2005).

\subsubsection{Soci-demographic Factors}

According to Al-Sadi and et al, (2010), increased educational opportunities for women and the level of education have led to increased productivity. Minniti and Bygrave (2003) argue that, though education is an important element of entrepreneurship, it has no direct relationship with the successful entrepreneurship; rather there are mixed results between education status and entrepreneurship ability. Formal education is not a prerequisite for becoming an entrepreneur. Available studies indicate that range of age is crucial for undertaking enterprises. In most cases, people within the age ranging from $20-34$ years are more likely to be entrepreneurs. Older age of people may have declined effects for entrepreneurship (Belwal, Al-Badi (2010). It is obvious that large family members have high consumption. In order to satisfy their need entrepreneurs having larger family size forced to devote more time in entrepreneurship activities to earn more money to satisfy their family need.

\subsubsection{Motivational Factors}

Another researcher on the same country had been conducted his study on Kitale municipality of Kenya also concluded that, women owned MSEs are experiencing low growth; even if a few small enterprises are experiencing high growth, the majority of micro enterprises are experiencing slow growth. The major factors that are affecting women MSEs growth negatively are motivation to do work (Oganchi, 2013). Need for achievement, independence, and self-reliant are the most important personality factors for business growth of women entrepreneurs and have a strong positive correlation with entrepreneurial success (Salfiya, 2012) on time decision has a great impact on business self-confident entrepreneurs can take a calculated risk and perform many actions by themselves(Hassan, 2013).

\subsubsection{Cultural Factors}

The perception of the society towards women entrepreneurs. Rigid social norms, values and attitude act as barrier in rural women entrepreneurship development (Afiya, 2012). The collaboration of the society with entrepreneurs. Social net works are crucial to the success of potential entrepreneurs (Zhen and et al, 2008). Women face additional or at least different social, cultural, educational and technological challenges than men when it comes to establishing and developing their own enterprises, and accessing economic resources (Pat and et al, 2004). Besides these, another authors on the same point described that the major factors that constrained women from business venture are mostly gender-based discrimination, and awareness about gender balanced participation in business (Afza, Hassan, \& Rashid, 2010).

\subsection{Entrepreneurship Theory}

Entrepreneurs innovate and innovation is considered as a critical driver of economic growth in the formulation of the endogenous growth theory (Abosede \& Onakoya, 2013). The critical dynamic driving force for entrepreneurship is innovation. But innovation is perceived differently in numerous theories as inventions, new combination, or inventive risk taking. Entrepreneurship theory suggests that the people and what they do determine economic development. The study of entrepreneurs as personalities scrutinizes the variables that describe their appearance, such as the psychological profile (the need for achievement, the capacity to control, tolerance of ambiguity and a tendency to take risks) or non-psychological variables (education, experience, networks, the family, etc.), and personal characteristics. Entrepreneurship is vital for economic progress as it manifests its fundamental importance in different ways: i) by identifying, assessing and exploiting business opportunities; ii) 
by creating new businesses and/or renovating surviving ones by making them more dynamic; and iii) by motivating the economy innovation, competence, job creation- and by generally improving the welfare of society (Álvaro, Domingo, \& Salvador, 2008).

Since entrepreneurship theory defend the idea of economic development coming as a result of the entrepreneurial activities of entrepreneurs. Which the researcher considered these activities as independent variables, the enterprenuership theory was found to be suitable for this study.

\subsection{Empirical Literature}

This section can present the review of empirical literature on the works of different scholars, researchers and practitioners on determinants of women entrepreneurs' performance.

Rajni and Mehta (2018) studied on determinants of women entrepreneurs' performance in Haryana, India. The result indicated that entrepreneurial competencies such as initiative, sees and acts on opportunities, knowing, commitment to work, systematic planning, problem solving, persuasion, monitoring and concern for employees' welfare were significantly correlated with entrepreneurial performance. Entrepreneurial competencies played complementary and supplementary role with growth in investment, sales growth, entrepreneurs' profit, yearly turnover and increase in the number of employees in the enterprise.

Welsh, Kaciak, and Shamah (2018) conducted a study on determinants of women entrepreneurs' firm performance in a hostile environment in Egypt. The study examines the determinants of firm performance for women entrepreneurs in the context of an emerging economy affected by a turbulent political and socio-cultural environment. The study draws from the resource-based and institutional-based views embedded in the genderaware 5M (money, management, market, macro/meso environments, and motherhood) model. A generalized structural equation model is used to analyze data from Egypt, the setting for this study. The study finds a positive relationship between women entrepreneurs' human capital and firm performance. However, no detectable relationship emerges between social capital and firm performance or between women's gender-related personal problems and firm performance. The findings suggest new boundary conditions in the domain of female entrepreneurship in a hostile environment, with important implications for practice and research.

Guci and Ghazali (2017) conducted a study on the determinants factors of performance of women entrepreneurs in indonesia- a study based on Batam City. The data self-collected, using quantitative based-study data was collected by surveyed questionnaire and analyzed by using Statistical Package for Social Science (SPSS). The questionnaires distributed were made up of four variables, where three were independent variables and one was dependent variable. By using a Spearman's correlation, it is found that each independent variable has strong correlation with the single variable. Essentially this research was conducted with two hundred respondents of women's micro businesses activity in Batam-Indonesia. Survey was conducted over Batam, Indonesia by dividing into three zone based on cluster north, middle and south. First zone is: Batu Ampar and Jodoh, followed by Sekupang and Nagoya and Batu Aji and Muka Kuning. There were several problems: the support from government is not comprehensive, no experience of women entrepreneurs by doing business and the attitude towards business not customer satisfaction oriented. The expected result indicated that the government support, experience, attitude towards business as the determinants factors and women entrepreneurs performance of Micro Enterprises have a relationship.

Saidi et al. (2017) conducted a study on determinants of women entrepreneurs' performance in SMEs in Malaysia. They found that education level, capital, and cultural are significant factors that could determine the performance of women entrepreneurs and their success. They also recommend that the women entrepreneurs are significant in economic growth of most countries around the world. Therefore, their involvement cannot be denied by all related parties. They should be given same treatment as male entrepreneurs in order to ensure their high involvement in this venture. Hence, this study is significant to bring new shed light to the literature in entrepreneurship, policymakers and academicians as a whole.

Hasan, and Almubarak (2016) conducted a study on factors influencing women entrepreneurs' performance in SMEs in Manama. The purpose of this paper is to contribute to the entrepreneurship literature by identifying factors influencing women entrepreneurs' performance (EP) and the corresponding challenges in small and medium enterprises (SMEs). The study also examines the opportunity recognition (OR) as a mediator between influencing factors and performance of women entrepreneurs. The study proposes a model that shows the effects of different internal and external factors on women EP. They found that the paper demonstrates several challenges that are encountered by women entrepreneurs such as lack of access to financial resources, difficulty in finding qualified labors, work-home conflict and low profit. The results suggest that the most influencing factor is industry (SMEs) characteristics followed by entrepreneurial goals and motivations (EGM), and legal factors. Additionally, OR is found to mediate EGM, and industry characteristics.

Kyalo (2016) studied on factors influencing performance of women entrepreneurs in Kenya: a case of Bungoma South and descriptive Research design was used to allow researcher to gather information, summarize, present and interpret data for the purpose of clarification. Stratified random sampling was used where each location 
formed strata. Proportional allocation was used to compute the exact number of subjects in each location which was a correct representation from the strata. The received data was classified, summarized, coded, sorted and SPSS and excel software used in analysis. From this study, it was observed that although there is the possibility of women entrepreneurs operating business enterprises in the same capacity and magnitude as men, traditional roles and practices such as domestic commitments, low levels of education, lack of property ownership and lack of opportunity driven motive to start enterprises continues to influence the performance of women entrepreneurs negatively in terms of monthly income sales, profit margin and types of business enterprise.

According to Amanuel (2012), a research conducted in Hosanna town at Hadiya Zone on challenges and opportunities of women entrepreneurs arrived to the following findings. They include discriminatory environment of women entrepreneurs in the study area, limitation on the service delivery of financial institutions, the issue of collaterals in MFI limited access to credit, limitation of searching new market by women entrepreneurs, training gap on basic business skills, self- employment problem, management skill gap of women entrepreneurs, lack of book keeping, lack of working premise facilitation by government, shortage of infrastructure facilities, limitation on grace periods for newly launched women entrepreneurs organization are what are recommended by the researcher based on his findings.

A research conducted by Mulugeta (2010) in Dessie town at Amahara Region, on factors affecting the performance of women entrepreneurs in MSEs identified that limitation of economy, social /cultural and legal/ bottlenecks, administrative bottlenecks, limited agents to support women entrepreneurs financially and lack of experience sharing are the main findings of his research.

According to Eshetu (2008) in his book of 'Women Entrepreneurship in Micro, Small and Medium Enterprises' describes women depend on MSMEs as a source of livelihood essentially because national governments fail to meet their requirements for survival and entrepreneurial aspiration. They have actively engaged and earn their livelihood in small enterprisers where government policies, regulations, owner's business skills, availability of finance, appropriate business trainings, and market matter most for their survival. Even though women entrepreneurs in Ethiopia start a number of new businesses, they find it harder to grow their business to the next higher level. Survival of a business firm is defined as the ability of the firm to continue its operation and remain in business during a certain period of time in a competitive market.

\subsection{Conceptual Framework of the Study}

As it is reviewed in the review of related literature section, the linkage between selected independent variables and performance of women entrepreneurs are presented in Figure 2.1. The conceptual framework constructed by modifying different literatures to suit the purpose of this study.

Figure 2.1: Conceptual Framework of the Study

$$
\text { Independent Variables }
$$

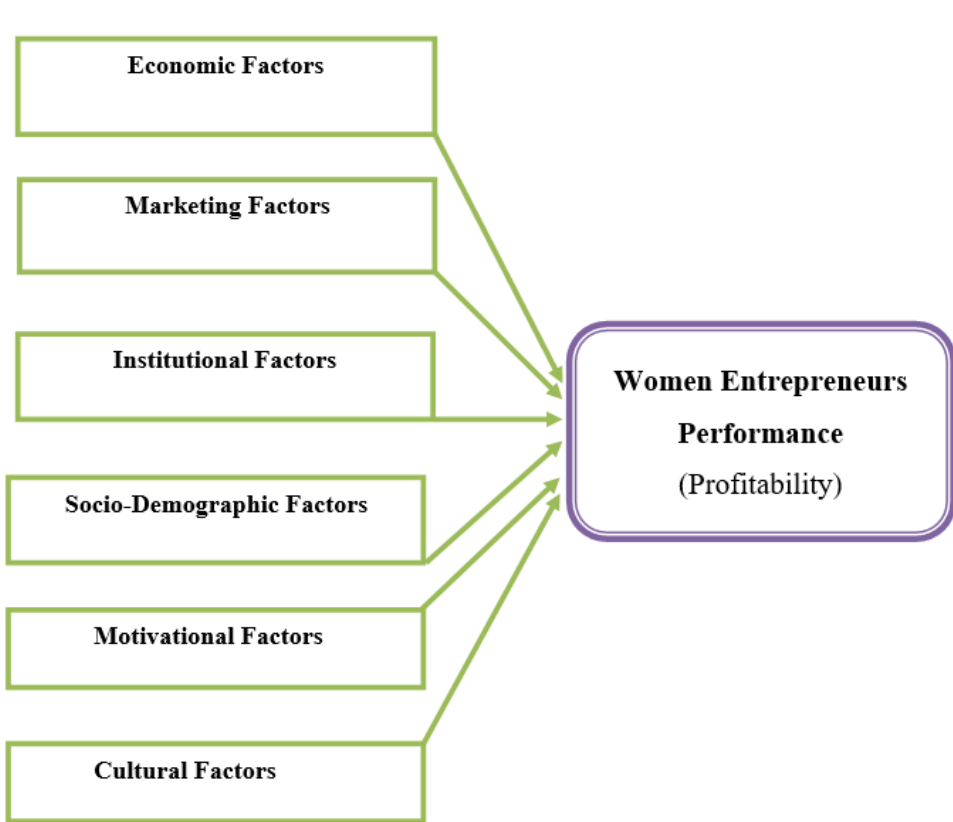

Source: Adapted from Bendixen and Migliorini (2006)

\section{RESEARCH METHODOLOGY}

This chapter includes description of the study area, research design, research approach, data sources, target 
population, sample size determination, sampling techniques, data collection methods, method of data analysis, and ethical consideration. The details are presented below.

\subsection{Description of the Study Area}

The study were conducted in Hawassa City Administration. Hawassa is located in Southern Nations, Nationalities, and Peoples Regional State on the shores of Lake Hawassa in the Great Rift Valley and served as the capital of the SNNPRS and Sidama Zone. It is situated at distance of $275 \mathrm{Kms}$ South of Addis Ababa. Geographically the city lays between 6054'-7060' latitude North and 38048'-38033' longitude East and the area is 157.25 Sq.Kms. Hawassa City is structured in eight Sub-Cities namely Misrak, Menehariya, Tabor, Mahal Ketema, Haykdar, Addis Ketema, Bahil Adarash, and Hawella Tulla (HCATID, 2016).

The total populations of Hawassa City are 343175; of which 176,599 are males and 166,576 are females. Of the total number of population in the city administration, 242,489 people live in urban area, while the remaining 129,337 people live in the rural areas with the annual growth rate of 4.02 . The dominant ethnic group in the city is Sidama (46.23\%); followed by Amhara (15.2\%), Wolayita (14.34\%), Oromo (5.13\%), Guragie (4.27\%), Kembata (2.7\%), Hadiya (1.37\%), Tigire (1.3\%), and others $(9.46 \%)$. The majority of the population of the city administration is Christians (90.27\%) which comprises of protestant (59.5\%), Orthodox (27\%) and Catholic $(3.77 \%)$. While the remaining $9.73 \%$ are Muslim $(8.1 \%)$, Traditional Believers $(0.14 \%)$ and others $(1.2 \%)$ (HCAFEDD, 2016).

\subsection{Research Design}

Explanatory research design is the best if the research question is to identify factors associated or to understand the best predictors of the dependent variable (Oleary, 2004). Therefore, the study employed explanatory research design.

\subsection{Research Approach}

The researcher used both quantitative and qualitative research approach. These approach refer to the type of data being collected (quantitative data involve numeric scores, metrics, and so on, while qualitative data includes interviews, and so forth) and analyze (i.e., using quantitative techniques such as regression or qualitative techniques such as narration). This is because the qualitative research approach enables to make subjective assessment of respondents. It is true that a good description provokes the 'why' questions of explanatory research. The quantitative approach helps to quantify or objectively measure certain variables in numeric terms, which makes descriptive analysis easy and manageable. Therefore, throughout the study, the researcher used both quantitative and qualitative research approach to compute and interpret numerical data and narrate and explain information obtained from qualitative data.

\subsection{Data Sources and Types}

Both primary and secondary data were collected from relevant sources that help to achieve the above objectives. The primary sources of information were collected from women entrepreneurs, trade and industry office official, revenue office official, omo micro-finance institution entrepreneur development center official, omo micro-finance women entrepreneurship development program official, and women, children and youth affair bureau. On the other hand, the secondary sources mostly include: books, articles, journals, research works, internet browsing, etc. that have relevance with the research topic. Regarding the types of data, it included both qualitative and quantitative information. The quantitative data were collected from women entrepreneurs through questionnaire whereas qualitative data were obtained from other officials through key informant interview.

\subsection{Target Population of the Study}

Target population is a total group of people from whom the researchers obtain information to meet the research objectives. Therefore, the target populations of the current study are 906 found in Meneharia, Haikdar and Taborsub cities. 
Table 3.1: Distribution of Women Entrepreneurs and Type of Enterprise

\begin{tabular}{|l|c|c|c|c|c|c|c|c|}
\hline $\begin{array}{c}\text { Types of } \\
\text { Enterprise }\end{array}$ & Misrak & Meneharia & Tabor & $\begin{array}{c}\text { Mahal } \\
\text { ketema }\end{array}$ & Haykdar & $\begin{array}{c}\text { Addis } \\
\text { ketema }\end{array}$ & $\begin{array}{c}\text { Bahil } \\
\text { adarash }\end{array}$ & $\begin{array}{c}\text { Hawella } \\
\text { Tula }\end{array}$ \\
\hline Manufacturing & 34 & 71 & 36 & 27 & 32 & 33 & 29 & 21 \\
\hline Construction & 28 & 70 & 100 & 32 & 31 & 27 & 32 & 25 \\
\hline Trade & 76 & 44 & 235 & 69 & 80 & 81 & 74 & 51 \\
\hline Service & 89 & 76 & 33 & 93 & 97 & 62 & 71 & 20 \\
\hline Total & $\mathbf{2 2 7}$ & $\mathbf{2 6 1}$ & $\mathbf{4 0 4}$ & $\mathbf{2 2 1}$ & $\mathbf{2 4 1}$ & $\mathbf{2 0 3}$ & $\mathbf{2 0 6}$ & $\mathbf{1 1 7}$ \\
\hline
\end{tabular}

Source: Trade and industry office (2018)

\subsection{Sampling Technique and Sample Size}

As per the report of Hawassa City trade and industry office (2018), about 906 women entrepreneurs which are found to be functional and have more than two years of work experience in selected sub-cities. Therefore, this data were used as a benchmark to calculate the sample size. Accordingly, the representative sample size was determined by using the formula developed by Yamane (1967) as follows:

$$
n=\frac{N}{1+N(e)^{2}}
$$

Where: $\boldsymbol{n}=$ Sample size

$\boldsymbol{N}=$ Total Population

$$
\boldsymbol{e}=\text { Sampling Error }
$$

Based on this formula, the total sample size of the study is determined as follows.

$$
\begin{aligned}
& n=\frac{N}{1+N(e)^{2}} \\
& n=\frac{906}{1+906(0.05)^{2}} \\
& n=\frac{906}{1+906(0.0025)} \\
& n \approx 278
\end{aligned}
$$

Therefore, 278 women entrepreneurs were determined as the total sample size of the study. In order to select the individual respondents, a multistage sampling procedure were applied. The stage wise sampling technique has been provided hereunder.

In the first stage of sampling, three sub cities such as Meneharia, Haikdar and Tabor were selected purposively from eight sub-cities since maximum number of registered and experienced women entrepreneurs found in these

\begin{tabular}{|c|c|c|c|c|c|c|c|c|}
\hline \multirow{3}{*}{ Types of Enterprise } & \multicolumn{6}{|c|}{ Selected Sub cities } & \multirow{2}{*}{\multicolumn{2}{|c|}{ Total }} \\
\hline & \multicolumn{2}{|c|}{ Haik Dar } & \multicolumn{2}{|c|}{ Menaheriya } & \multicolumn{2}{|c|}{ Tabor } & & \\
\hline & $\mathbf{N}_{1}$ & $\mathbf{n}_{1}$ & $\mathbf{N}_{2}$ & $\mathbf{n}_{2}$ & $\mathbf{N}_{3}$ & $\mathrm{n}_{3}$ & $\mathbf{N}$ & $\mathbf{n}$ \\
\hline Manufacturing & 33 & 10 & 44 & 14 & 36 & 11 & 113 & 35 \\
\hline Construction & 31 & 10 & 70 & 21 & 33 & 10 & 134 & 41 \\
\hline Trade & 80 & 24 & 71 & 22 & 235 & 72 & 386 & 118 \\
\hline Service & 97 & 30 & 76 & 23 & 100 & 31 & 273 & 84 \\
\hline Total & 241 & 74 & 261 & 80 & 404 & 124 & 906 & 278 \\
\hline
\end{tabular}
sub cities. In the second stage of sampling, among 1200 women entrepreneurs which were registered in the above sample sub-cities, 906 functional women entrepreneurs were identified and selected purposively based on the functionality of the enterprise. In the third stage of sampling, proportional number of women entrepreneurs were selected from each types of business based on proportional stratified sampling technique (see Table 3.2).

Table 3.2: Sampled Women Entrepreneurs and Type of Enterprise

Source: Own computation from trade and industry office (2018)

$\mathrm{nk}=\frac{n * N K}{N} \quad \mathrm{nk}=$ The sample size for $\mathrm{k}^{\text {th }}$ strata.

$\mathrm{Nk}=$ the population size of $\mathrm{k}^{\text {th }}$ strata.

$\mathrm{N}=$ the total population size.

$\mathrm{n}=$ the total sample size.

In the fourth stage of sampling, an individual respondent in each sample enterprise were selected using systematic random sampling technique to ensure that there is no over or under representation in the sample as it is in the sampling frame (Bhattacherjee, 2012). In systematic random sampling, the respondents were selected from the list of women entrepreneurs by $\mathrm{k}^{\text {th }}$ interval $\left(\mathrm{k}=\mathrm{N}_{\mathrm{i}} / \mathrm{n}_{\mathrm{i}}\right.$. Accordingly, if the first individual (i) would be selected 
randomly from between 1 and $k$, and the next member would be $(i+k)^{\text {th }}$, then $(i+2 k)^{\text {th }}$, and follows for each types of enterprise in the same fashion until 278 respondents was achieved.

\subsection{Data Collection Tools}

The study employed different data collection tools. Questionnaire and key informant interview were employed to collect quantitative data and key informant interview were employed for collecting qualitative data.

\subsection{Inferential Analysis}

\subsubsection{Correlation Analysis}

The correlation coefficients value range from -1 (a perfect negative relationship) to +1 (a perfect positive relationship) or a direct relationship between two variables. A value of 0 indicates no linear relationship between two variables (Kothari, 2004). In order to identify their individual relation with the dependent variable, the independent variables were analyzed one by one using correlation analysis. Therefore, independent variables such as age, family size, business experience, economic factors, institutional factors, marketing factors, motivation factors, and cultural factors were tested their degree of relationship with women entrepreneurs performance before conducting the regression analysis. To know the strength and type of correlation between variables, the following table set as a rule of thumb for discussion of variables.

Table 4.3: Correlation Analysis Result

\begin{tabular}{|l|l|l|l|l|l|l|l|l|l|}
\hline & \multicolumn{1}{|c|}{ Ag } & \multicolumn{1}{|c|}{ FS } & BExp & EF & IF & MktF & MF & CF & WEP \\
\hline Ag & 1 & & & & & & & & \\
\hline FS & -.008 & 1 & & & & & & & \\
\hline BExp & $-.154^{* *}$ & -.014 & 1 & & & & & & \\
\hline EF & $-.166^{* *}$ & $-.323^{* *}$ & $.197^{* *}$ & 1 & & & & & \\
\hline IF & .024 & -.095 & $.192^{* *}$ & $.186^{* *}$ & 1 & & & & \\
\hline MktF & $-.289^{* *}$ & $-.316^{* *}$ & $.274^{* *}$ & $.575^{* *}$ & $.149^{*}$ & 1 & & & \\
\hline MF & $-.178^{* *}$ & $-.260^{* *}$ & $-.217^{* *}$ & $.599^{* *}$ & $.127^{*}$ & $.455^{* *}$ & 1 & & \\
\hline CF & $-.187^{* *}$ & $-.161^{* *}$ & $.330^{* *}$ & $.475^{* *}$ & $.148^{*}$ & $.394^{* *}$ & $.287^{* *}$ & 1 & \\
\hline WEP & $-.229^{*}$ & $-.317^{* *}$ & $.522^{* *}$ & $.818^{* *}$ & $.266^{* *}$ & $.739^{* *}$ & $.507^{* *}$ & $.545^{* *}$ & 1 \\
\hline
\end{tabular}

Source: Own survey data, 2018

**Correlation is significant at the 0.01 level (2-tailed)

*. Correlation is significant at the 0.05 level (2-tailed).

As Table 4.8 presents, age has negative and statistically significant association with women entrepreneurs' performance $(r=-0.229, p<0.01)$. As well, family size has negative and statistically significant relationship with women entrepreneurs' performance $(\mathrm{r}=-0.317, \mathrm{p}<0.01)$. Similarly, business experience has positive and statistically significant relationship with women entrepreneurs' performance $(r=0.522, p<0.01)$. Also, economic factors have positive and statistically significant relationship with women entrepreneurs' performance $(\mathrm{r}=0.818$ $\mathrm{p}<0.01$ ). Correspondingly, institutional factors have positive and statistically significant relationship with women entrepreneurs' performance $(\mathrm{r}=0.266, \mathrm{p}<0.01)$. Additionally, marketing factors have positive and statistically significant relationship with women entrepreneurs' performance $(r=0.739, p<0.01)$. Furthermore, motivation factors have positive and statistically significant relationship with women entrepreneurs' performance $(r=0.507$, $\mathrm{p}<0.01)$. Lastly, cultural factors have positive and statistically significant relationship with women entrepreneurs' performance $(\mathrm{r}=0.545, \mathrm{p}<0.01)$. Based on Bhattacherjee (2012) rule of thumb, the result implies that some of the independent variables have weak and moderate correlation to each other but they have weak, moderate strong and very strong relationship to the dependent variable.

\subsubsection{Regression analysis}

Since multiple linear regression analysis facilitates the evaluation of the level of effect that multiple independent variables that cause on a particular dependent variable, multiple linear regression analysis is applied. Before applying regression analysis, all the necessary assumptions were made.

Table 4.4: Results of Regression Analysis Model Summary

\begin{tabular}{|c|c|c|c|c|}
\hline Model & R & R Square & Adjusted R Square & Std. Error of the Estimate \\
\hline 1 & $.949^{\mathrm{a}}$ & .901 & .898 & 349.134 \\
\hline
\end{tabular}

a. Predictors: (Constant), Cultural Factors, Institutional Factors, Family size, Age, Business experience,

Motivation Factors, Marketing Factors, Economic Factors, Education level

b. Dependent Variable: Profit

Source: Own survey data, 2018

The result of Table 4.10 shows that the $\mathrm{R}$ value of the model was 0.949 which shows the highest degree of relationship between independent and dependent variables. The adjusted $\mathrm{R}^{2}$ value of the regression model was 0 . 898 , indicating that $89.8 \%$ of variance in women entrepreneurs performance was accounted by socio-demographic 
factors, economic factors, institutional factors, marketing factors, motivation factors and cultural factors. The remaining $10.2 \%$ of variance in women entrepreneurs' performance was accounted by other factors which were not included in this study.

Table 4.5: Results of ANOVA Output

\begin{tabular}{|l|l|c|c|c|c|c|}
\hline \multicolumn{2}{|l|}{ Model } & Sum of Squares & df & Mean Square & F & Sig. \\
\hline \multirow{4}{*}{1} & Regression & 298368285.850 & 9 & 33152031.761 & 271.973 & $.000^{\mathrm{b}}$ \\
\cline { 2 - 7 } & Residual & 32667685.373 & 268 & 121894.348 & & \\
\cline { 2 - 7 } & Total & 331035971.223 & 277 & & & \\
\hline
\end{tabular}

a. Dependent Variable: Profit

b. Predictors: (Constant), Cultural Factors, Institutional Factors, Family size, Age, Business experience,

Motivation Factors, Marketing Factors, Economic Factors, Education level

Source: Own survey data, 2018

As Table 4.11 shows that the ANOVA table indicated that the multiple regression model itself is statistically significant or not significant. The f-ratio is used to test whether or not $\mathrm{R}^{2}$ could have occurred by chance alone. In short, the f-ratio found in the ANOVA table measures the probability of chance departure from a straight line. On results of the output found in the ANOVA table, the model is statistically significant when socio-demographic factors, economic factors, institutional factors, marketing factors, motivation factors and cultural factors were included $(\mathrm{F}=271.973, \mathrm{p}<0.001)$. Therefore, the overall equation was found to be statistically significant.

Table 4.6: Results of Multiple Linear Regression Analysis

\begin{tabular}{|c|c|c|c|c|c|c|}
\hline \multirow{2}{*}{\multicolumn{2}{|c|}{ Model }} & \multicolumn{2}{|c|}{ Unstandardized Coefficients } & \multirow{2}{*}{$\begin{array}{c}\text { Standardized Coefficients } \\
\text { Beta }\end{array}$} & \multirow[b]{2}{*}{$\mathrm{t}$} & \multirow[b]{2}{*}{ Sig. } \\
\hline & & $\mathrm{B}$ & Std. Error & & & \\
\hline \multirow[t]{10}{*}{1} & (Constant) & 3390.520 & 258.460 & & 13.118 & .000 \\
\hline & Age & 1.793 & 1.989 & .018 & .901 & .368 \\
\hline & Education level & 204.673 & 42.455 & .164 & 4.821 & .000 \\
\hline & Family size & -9.602 & 9.992 & -.020 & -.961 & .337 \\
\hline & Business experience & 50.140 & 3.601 & .348 & 13.922 & .000 \\
\hline & Economic Factors & 390.312 & 32.071 & .385 & 12.170 & .000 \\
\hline & Institutional Factors & 19.225 & 16.376 & .024 & 1.174 & .241 \\
\hline & Marketing Factors & 430.603 & 52.153 & .228 & 8.257 & .000 \\
\hline & Motivation Factors & 304.559 & 55.137 & .157 & 5.524 & .000 \\
\hline & Cultural Factors & 24.473 & 25.276 & .023 & .968 & .334 \\
\hline
\end{tabular}

Note: $B=$ Regression coefficient (Estimate), Std.Error $=$ Standard Error, Dependent variable $=$ Market Performance

Source: Own survey data, 2018

\subsection{Summary of Findings}

The basic purpose of this study was to identify the determinants of women entrepreneurs' performance in Hawassa city administration, Southern Nations Nationalities and Representative State, Ethiopia. A total of 278 women entrepreneurs were participated in responding the questionnaire and the collected data were analyzed using descriptive statistics such as frequency, percentage, mean and standard deviation. Furthermore, inferential statistics such as correlation and multiple linear regressions were used. Based on the information from analysis and discussion parts, the following summaries are made:

- In relation to background characteristics of women entrepreneurs, the majority $(82.7 \%)$ of them were found in the age group of 25-34. Additionally, half of women entrepreneurs had certificate and above. Similarly, the majority $(53.6 \%)$ of them were single. Also, the majority $(86.3 \%)$ of women entrepreneurs' family size was in between 1 and 5. Furthermore, their average business experience was 4.79 years and their average last year profit was 9158.27 birr. The majority $(67.7 \%)$ of them start their own business to be self-employed.

- The ranges of values were presented as disagreeing if the mean score is between 1.00 and 2.60, neutral if the mean score is between 2.60 and 3.40 and agree if the mean score is above 4.20. Therefore, the interpretations of all Likert scale items such as economic factors, institutional factors, marketing factors, motivation factors, and cultural factors were presented were done based on these classifications.

- Based on the result, women entrepreneurs were tended to the idea of disagreement on cultural factors (M $=2.23, \mathrm{SD}=1.012)$. Furthermore, they were tended to the idea of agreement on economic factors $(\mathrm{M}=3.62$, $\mathrm{SD}=1.079)$, institutional factors $(\mathrm{M}=3.72, \mathrm{SD}=1.349$, marketing factors $(\mathrm{M}=3.97, \mathrm{SD}=0.578)$, and motivation factors $(\mathrm{M}=4.52, \mathrm{SD}=0.565)$.

- The results of the correlation analysis indicated that age $(r=-0.229, p<0.01)$, family size $(r=-0.317, p<0.01)$, business experience $(r=0.522, p<0.01)$, economic factor $(r=0.818 p<0.01)$, institutional factor $(r=0.266$, 
$\mathrm{p}<0.01)$, marketing factor $(\mathrm{r}=0.739, \mathrm{p}<0.01)$, motivation factor $(\mathrm{r}=0.507, \mathrm{p}<0.01)$ and cultural factors $(\mathrm{r}$ $=0.545, \mathrm{p}<0.01$ ) have statistically significant relationship with women entrepreneurs' performance. The result shows that some of the independent variables have weak and moderate correlation to each other but they have weak, moderate, strong and very strong relationship to the dependent variable.

- The result of the model summary of multiple linear regression analysis indicated that the overall relationship between the dependent and independent variables is strong $(\mathrm{R}=0.949)$.

- The adjusted $\mathrm{R}^{2}$ value of the regression model was 0.898 , indicating that $89.8 \%$ of variance in women entrepreneurs performance was accounted by socio-demographic, economic factors, institutional factors, marketing factors, motivation factors and cultural factors. The remaining $10.2 \%$ of variance in women entrepreneurs' performance was not accounted by socio-demographic factors, economic factors, institutional factors, marketing factors, motivation factors and cultural factors.

- The ANOVA table indicated that the multiple regression model itself is statistically significant or not significant. Accordingly, it is found that the model is statistically significant when age, education level, family size, business experience, economic factors, institutional factors, marketing factors, motivation factors and cultural factors were included $(\mathrm{F}=271.973, \mathrm{p}<0.001)$. Therefore, the overall equation was found to be statistically significant.

\subsection{Recommendations}

In order to fill the identified gaps of women entrepreneurs' performance in the study area, the following recommendations are forwarded based on major findings and conclusion.

- It is found that leaving the to total household responsibility to women enterprenuers decrease their performance. Therefore, the household members should support women entrepreneurs by sharing the home responsibilities of women's to devote all their efforts in the business, also women's should have to share their responsibilities to others.

- Education level is found to be a significant factor for women entrepreneurs' performance. So that the administration government should design the formal mode of education for women who did not attend formal education to enable them at least to read and write; thereby grasping coffee marketing members' knowledge and get an access to different advanced market communication media.

- Experienced women entrepreneurs were benefited to sell more of their product. Therefore, the Hawassa city administration in collaboration with other stakeholders should give training to enable them to be more productive. In addition, they should facilitate the women entrepreneurs' to have knowledge share program among each other.

- Economic factors were found to be determinants of women entrepreneurs' performance. Which means it is the base for women entrepreneurs' performance. Therefore, financial institutions in the city should arrange long-term financial credit for women entrepreneurs. To increase capital and to expand the existing business the city cooperative promotion office, unions and other concerned stakeholders should involve in designing a mechanism to promote women entrepreneurs saving and to increase their profit.

- Marketing is a factor that affects the performance of women entrepreneurs. Therefore, the Hawassa city administration in collaboration with trade and industry office needs to involve effectively in supporting women entrepreneurs by offering convenient display room and selling premises. To search market and to sell their product at a better price, trade and industry office should create market linkage with unions, cooperatives, government organizations and NGOs.

- Motivational factors found to be a significant factor that affects the performance of women entrepreneurs. Therefore, in order to increase their profit, women entrepreneurs should have the desire for achievement, independence, wealth and self-discovery and job satisfaction.

\section{References}

Abosede, A. J., \& Onakoya, A., B. (2013). Intellectual Entrepreneurship: Theories, Purpose and Challenges. International Journal of Business Administration (45), 30-37.

Adnan, A. (2004). Gender Entrepreneurship, Fundamentals of Entrepreneurship. Selangor: Pearson, Prentice Hall

Afza, T., Osman, M. H., \& Rashid, M. A. (2010). Enterprising Behavior of Enterprise-less Rural Women Entrepreneurs of Khyber Pukhtan Khawa of Pakistan. European Journal of Social Sciences, 18(1), 109-119.

Álvaro C., D., \& Salvador, R. (2008). Entrepreneurship: Concepts, Theory and Perspective. Introduction. Madrid: Universitat de València.

Amananuel, Degefa. (2012). Challenges and Opportunities of Women Entrepreneurs, the case of Hadiya Zone, Hossana Town (Unpublished master's thesis). Hawassa University, Hawassa.

Begley, T. M. (1995). Using Founder Status, Age of Firm, and Company Growth Rate as the Basis for Distinguishing Entrepreneurs from Managers of Small Businesses. Journal of Business Venturing, 10, 249- 
263.

Bendixen \& Migliorini. (2006). Entrepreneurship and women: The Making of a Business Plan for the Creation of a Distribution Business in Denmark (Unpublished Master's Thesis).

Bhattacherjee, A. (2012). Social Science Research: Principles, Methods, and Practices. University of South Florida: Scholar Commons.

Buttner, H. E., \& Moore, D. P. (1997). Women's Organizational Exodus to Entrepreneurship: Self-Reported Motivations and Correlates with Success. Journal of Small Business Management, 35(1), 34-46.

Chu, P. (2000). The Characteristics of Chinese Female Entrepreneurs: Motivation and Personality. Journal of Enterprising Culture, 8(1), 67-84.

Creswell, J. (2009). Research Design: Qualitative, Quantitative and Mixed Methods Approaches (3rd ed.). Sage Publications, Inc.

Cromie, S., \& Hayes, J. (1988). Towards a Typology of Female Entrepreneurs. The Sociological Review, 36(1), $87-113$

CSA. (2016). Key findings on the 2016 urban employment unemployment survey. Addis Ababa, Ethiopia.

Cull, R. (2009). Microfinance Meets the Market. Journal of Economic Perspectives, 23(1), 167-92.

Dinh, T. (2011). Light Manufacturing in Developing Countries. A Strategy for Job Creation and Prosperity, JEL Classification Numbers: L60, O14, O25, O55, 2-10. P. 194. doi: 10.6007/IJARBSS/v3-i10/289.

Dzisi, S. (2008). Women Entrepreneurs in Small and Medium Enterprises (SMEs) in Ghana. Victoria: Swinburne University of Technology. Retrieved from http://www.unece.org/gender/documents/Overview.pd

Geneti, Y. T. (2018). Challenges and Opportunities of Micro and Small Enterprises Strategy in Ethiopia Urban Development: the Case of Ambo Town, Oromia Ethiopia. SDMIMD Journal of Management, 9(1), 55-64.

George, D., \& Mallery, P. (2003). SPSS for Windows step by step: A simple guide and reference 11.0 update (4th ed.). Boston: Allyn \& Bacon

Global entrepreneurship monitors (GEM). (2010). global report fifteen years of assessing entrepreneurship across the globe. United Kingdom Founding Institution: London Business School, London.

Guci, D. A., \& Ghazali, P. L. (2017). Determinants Factors of Performance of Women Entrepreneurs in IndonesiaA Study Based on Batam City. World Applied Sciences Journal, 35(8), 1616-1619.

Gujarati, D.N. (2003). Basic Economics (2nd ed.). Mc Graw hill, Inc.: New York.

Hasan, F. S.M., \& Almubarak, M. M. (2016). Factors influencing women entrepreneurs' performance in SMEs. World journal of entrepreneurship management and sustainable development, 12(2), 82-101. doi:10.1108/WJEMSD-09-2015-0037.

Hassan, B. (2013). Determinants of Growth for Women Owned and Operated Micro Enterprises. Retrieved from: http://www.ijbcnet.com and accessed on May, 2018.

Hattab, H. (2008). Global Entrepreneurship Monitor: Entrepreneurship Report. Egypt, Industrial Modernization Centre.

Hausmann, T. L., \& Zahidi. S. (2012). World Economic Forum: The Global Gender Gap Report, ISBN 92-9504478-9, ISBN 978-92-95044-78-4. P. 29.

HCATID. (2016). Hawassa City Administration Trade and Industry Department Annual Report. Hawassa: Ethiopia.

International Development Research Centre ([IDRC], 2013). Learning by text or content? [Review of the book Growth and economic opportunities for women, by Canada Literature Review to IDRC]. The William and Flora Hewlett Foundation, p. 7-9

Jennings, D. F. (1994). Multiple Perspectives of Entrepreneurship: Text, Readings, and Cases. Cincinnati, Ohio: South - Western Publishing Company

Kyalo, M. E. (2016). Factors Influencing Performance of Women Entrepreneurs in Kenya: A Case of Bungoma South (Unpublished master's thesis). Nairobi, Kenya.

Mabala, R.(2011). Youth and "the hood" - livelihoods and neighborhoods, Environment and Urbanization, 123, $157-181$

Moore, D. P. (1990). An Examination of Present Research on the Female Entrepreneur: Suggested Research Strategies for the 1990s. Journal of Business Ethics, 9(4-5), 275-281.

Mulugeta Chane. (2010). Factors Affecting the Performance of Women Entrepreneurs in Micro and Small Enterprises in Dessie Town (Unpublished master's thesis). Bahir Dar University, Bahir Dar.

Ngare, M. (2013). Female Enterprise Development: A Case study of graduate women in Nairobi (Unpublished master's thesis).

Nkurunziza, J. (2012). Entrepreneurship and income level in developing countries, United Nations. Conference on Trade and Development [UNCTAD], Geneva.

Oganchi, N. (2013). A Survey of Kitale Municipality. International Journal of Academic Research in Business and Social Sciences, 3(10). ISSN: 2222-6990.

Oleary, Z. (2004). The Essential Guide to doing research. London: SAGE. 
Onuoha, G. (2007). Entrepreneurship. AIST International Journal 10, 20-32.

Orwa, H. (2012). Performance of Women in Small Scale Enterprises: Marital Status and Family Characteristics. European Journal of Business and Management. Retrieved from htt://www.ku.ac.ke and accessed on May, 2018. http://www.entrepreneur.com/tradejournals/article/196723352.html

Rahel \& Paul. (2010). Growth Determinants of Women-Operated Micro and Small Enterprises in Addis Ababa. Journal of Sustainable Development in Africa, 12(6), 234-237.

Rajni \& Mehta, S. (2018). Determinants of women entrepreneurs' performance in Haryana, India. Int. J. Curr. Microbiol. App. Sci, 7(10), 193-202. doi:10.20546/ijcmas.2018.710.020.

Saidi, N. A., Rashid, N. A., Zin, N. M., Ramlan, H., Johari, N and Mohamad, M. (2017). Determinants of Women Entrepreneurs' Performance in SMEs. International Symposium \& Exhibition on Business and Accounting. Retrieved from http://www.acadmia.edu

Trade and industry office.(2018). Anuual reports of Hawassa City trade and industry office. Hawassa ,Ethiopia.

Ummah, S. (2012). Factors Influencing on Entrepreneurial Success: An Empirical Study on Women Headed Families in Ampara and Batticaloa Districts in Ssri Lanka. International Journal of Business, Economics and Law, 1 (147). Retrieved from http://ijbel.com/ and accessed on May, 2018.

Vusumuzi, N. G. (2011). Challenges Faced by Urban Zimbabwean Women Entrepreneurs (Unpublished doctoral dissertation). University of the Free State, Zimbabwe. Retrieved from htt:/www.etd.uovs.ac.za/ETDdb/theses/available/etd-08152012.../NaniGV.pdf and accessed on May, 2018.

Welsh, D. H. B., Kaciak, E., \& Shamah, R. (2018). Determinants of women entrepreneurs' firm performance in a hostile environment, Egypt. Journal of Business Research, 88, 481-491. doi: 10.1016/j.jbusres2017.12.015.

Yamane, T. (1967). Statistics, an Introductory Analysis (2 ${ }^{\text {nd }}$ ed.). New York: Harper and row. 